\title{
THE PRIVY COUNCIL AS THE FINAL COURT FOR THE BRITISH EMPIRE
}

\author{
Rt Hon Sir Ivor Richardson*
}

After introductory comments on how the Judicial Committee functioned as the final court for the British Empire for over a century, this article discusses a range of highly unusual cases from India, Canada and New Zealand. The aim is to give something of the flavour of the Judicial Committee's work and its impact on local courts. The final section of the paper suggests conclusions that can be drawn from that survey.

\section{INTRODUCTION}

The Judicial Committee of the Privy Council Act 1833 provided the framework for the hearing of appeals against decisions of final courts in the far-flung reaches of the Empire. And, as we shall see, the functioning of the Privy Council evolved along with changes in the governance arrangements for the colonies and territories.

In 1839, the Earl of Durham, whose principal adviser was Edward Gibbon Wakefield, presented his landmark report on the specific problems of Canadian governance together with proposals for resolving them, which Piers Brendon notes, "were so universal in their application that the Durham Report became a handbook of white colonial development under the Union Jack."1

To the same effect, Professor Niall Ferguson concludes that the Durham Report has a good claim to be the book that saved the Empire, adding that: ${ }^{2}$

By the 1860s the balance of political power in all the white colonies had been decisively shifted ... real power would lie with the colonists' elected representatives. 'Responsible government', then, was a way of reconciling the practice of empire with the principle of liberty. What the Durham Report meant was

* Distinguished Fellow, Victoria University of Wellington Law Faculty. Professor of Law at Victoria University of Wellington 1967-1973; Dean of the Law Faculty at Victoria University of Wellington 19681971; Pro-Chancellor of Victoria University from 1979-1984; Chancellor of Victoria University 1984 1986; appointed to the Court of Appeal 1977; President of the Court of Appeal in 1996-2002.

1 Piers Brendon The Decline and Fall of the British Empire 1781-1997 (Vintage Books, London, 2008) at 81.

2 Niall Ferguson Empire: How Britain Made the Modern World (Penguin Books, London, 2004) at 112. 
that the aspirations of Canadians, Australians, New Zealanders and South Africans - which were to be little different from the aspirations of the Americans in the 1770s - could be and would be answered without the need for wars of independence. From now on, whatever the colonists wanted, they pretty much got.

The British North America Act 1867, s 3 created "one Dominion under the name of Canada" to describe the confederation of the colonies of British North America which took place that year. In the early 1900s the term "Dominions" gained currency outside Canada to denote the self-governing countries of the British Empire: Canada, South Africa, Australia and New Zealand. These countries had by then enjoyed a substantial measure of self-government, which distinguished them from the more dependent territories of the Empire. ${ }^{3}$ That growing equality in status with Britain was reflected in the adoption of the wider expression, British Commonwealth of Nations. Through all these changes the long heyday of the Judicial Committee lasted for over a century until inevitably Canada, South Africa, India and Australia had elected to rely on their own final courts.

In an after-dinner address published under the title "The Work for the Empire of the Judicial Committee of the Privy Council" Viscount Haldane explained the role of the Committee: ${ }^{4}$

We sit there to administer Buddhist law, or Hindu law, or Mohammedan law, one after the other. We administer Roman-Dutch law from South Africa or from Ceylon, or French law from Quebec, or the common law of England from Ontario, or curious mixtures of law which prevail in various colonies, sometimes Italian law, sometimes Roman law. We sit there and do our best.

Much greater depth was reflected in the determination of appeals than that light-hearted comment might suggest. India is the best example. The long involvement of English administrators, lawyers and judges in the development of laws in India, including the work of Law Commissions and the development of statutory Indian codes in many fields was crucial. It was helpfully reviewed by MC Setalvad, formerly Attorney-General of India, in the Lionel Cohen Lectures on "The Role of English Law in India" at the Hebrew University of Jerusalem. ${ }^{5} \mathrm{Mr}$ Setalvad concluded his assessment of the reception of English law before independence in this way: ${ }^{6}$

It would be true to say that the foundation of all law in India, civil or criminal law, is English law as constituted by the common and statute law of England and the judicial decisions of its courts. Nevertheless, the principles drawn from these sources have been largely and in numerous matters

3 PW Hogg Constitutional Law of Canada (4th ed, Carswell, Toronto, 1997) at [5.1(e)].

4 Viscount Haldane "The Work for the Empire of the Judicial Committee of the Privy Council" (1921) 1 CLJ 143 at 148 .

5 MC Setalvad The Role of English Law in India (Magnes Press, Jerusalem, 1966), distributed in Great Britain, the British Commonwealth and Europe by the Oxford University Press.

6 At 36. 
subjected to changes to adapt them to Indian conditions so that notwithstanding the main sources from which it is drawn Indian jurisdiction can still rightly be called Indian in its structure and operation.

Next, the huge volume of Indian appeals resulted in the bulk of the work of the Judicial Committee coming from that jurisdiction. The regular participation of those experienced in Indian law ensured that the English-based judges were familiar with the background. To illustrate the last point, the Judicial Committee Act 1871, s 1 empowered the Crown to include in the four paid members of the Judicial Committee the Chief Justice of the High Court in Bengal, Madras or Bombay. Sir James Colville, who had earlier been an Indian assessor to the Judicial Committee, and Sir Barnes Peacock, were appointed in that capacity. Browsing through Moore's Indian Appeals series from 1836 to 1872 and the 78 volumes of the Law Reports Indian Appeals series from 1873 to 1950 , brings home that, whether described as 'assessors' or simply as members of the Board, judges with long experience in India regularly sat on Indian cases.

Indian appeals dominated the workload of the Judicial Committee. That is illustrated by the "Table of Appeals disposed of by the Judicial Committee 1925-1931" set out in Professor Enid Campbell's pioneering study "The Decline of the Jurisdiction of the Judicial Committee of the Privy Council". ${ }^{7}$ The total appeals for those 7 years are: ${ }^{8}$

$\begin{array}{lr}\text { India } & 659 \\ \text { Ceylon } & 22 \\ \text { Canada } & 131 \\ \text { Australia } & 35 \\ \text { New Zealand } & 15 \\ \text { South Africa } & 0 \\ \text { Colonies } & 90 \\ \text { Total } & 952\end{array}$

The right of appeal from South Africa became in practice a dead letter and between 1909 and 1950 when the appeal regime ceased, only 10 appeals were heard. In only one of those was the decision of the Appellate Division of the Supreme Court reversed. ${ }^{9}$

Professor Campbell adds that judging by the post-War cases from Australia, the Judicial Committee's Australian business was almost confined to governments, corporations, associations or

7 Enid Campbell "The Decline of the Jurisdiction of the Judicial Committee of the Privy Council" (1959) 33 ALJ 196 at 209.

8 Ibid. Note: only 50 (or five per cent) came from Australia and New Zealand.

9 Ibid at 202. 
substantial financial interests. ${ }^{10}$ The table records that only five appeals from State courts were heard between 1949 and $1955 .{ }^{11}$

There is also an extended discussion of the functioning of the Judicial Committee in Geoffrey Lewis's Lord Atkin, ${ }^{12}$ and in RFV Heuston's Lives of the Lord Chancellors $1885-1940 .{ }^{13}$ Heuston speaks of Viscount Haldane's "influence on the constitutional law of Canada [as having been] profound", noting that between 1912 and 1929, 41 appeals to the Judicial Committee raised questions concerning the validity of Canadian legislation. ${ }^{14}$ He was a member of the Board in 32 of these appeals and delivered the judgment in 19.

The Rt Hon Sir John Rankin's article, "The Judicial Committee of the Privy Council", records that appeals entered 1928-1937 totalled 752 from India and 428 from other courts. ${ }^{15}$ To round off the computations, JP Eddy KC, in "India and the Privy Council: The Last Appeal" notes that in the last four years before appeals ceased, 182 appeals were heard. ${ }^{16}$

Sir John Rankin also cites a passage from the judgment in Hull and Co v McKenna where Lord Haldane said: ${ }^{17}$

It is also necessary to keep a certain discretion, because when you are dealing with the Dominions you find that they differ very much ... For instance, in India leave to appeal is more freely given than elsewhere, but the genesis of that is the requirements of India, and the desire of the people in India. In South Africa, we take the general sense of that Dominion into account, and restrict the cases in which we advise His Majesty to give leave to appeal. It becomes with the Dominions more and more or less and less as they please. We go upon the principles of autonomy on this question of exercising the discretion as to granting leave to appeal.

Sir John Rankin goes on to say that: ${ }^{18}$

10 Ibid at 204.

11 Ibid at 209.

12 Geoffrey Lewis Lord Atkin (Butterworths, London, 1983) at 94-117.

13 RFV Heuston Lives of the Lord Chancellors 1885-1940 (Clarendon Press, Oxford, 1964) at 213-218 and 239-240.

14 At 216

15 John Rankin "The Judicial Committee of the Privy Council" (1939) 7 CLJ 1 at 22.

16 JP Eddy "India and the Privy Council: The Last Appeal" (1950) 66 LQR 206 at 214.

17 Hull and Co v McKenna [1926] Ir R 402 (PC) at 404-405 (not reported in the Appeal Cases).

18 John Rankin "The Judicial Committee of the Privy Council", above n 15, at 15. 
A less friendly critic might reflect that the demands of unsuccessful litigants, of the legal profession, of the Government or Governments and the desire of the people in India or elsewhere - may be widely discrepant and in some cases difficult to ascertain.

An overall review of the jurisprudence of the Judicial Committee would be an immense task. Many highly unusual cases have come before the Committee over the years. Something of the flavour of the breadth of its work and its impact on local courts may come through from a discussion of a range of cases, starting with an extraordinary Indian case and going on to discuss several striking cases from Canada and New Zealand.

\section{INDIA: SRIMATI AND CONCURRENT FINDINGS OF FACT}

Srimati Bibhabati Devi v Kumar Ramendra Narayan Roy is still the leading authority on the practice of the Board where there are concurrent judgments in the courts below on a pure question of fact. ${ }^{19}$ It was so cited in the New Zealand decision of the Judicial Committee in Gilrose Finance Ltd v Ellis Gould. ${ }^{20}$

The members of the Board were Lord Thankerton, Lord du Parcq and Sir Madhavan Nair (a very eminent Indian judge). Lord Thankerton immediately emphasised that the appellant was faced with the concurrent judgments of two courts on a pure question of fact, with the practice of the Board being to decline to review the evidence for a third time unless there were some special circumstances which would justify a departure from that practice. ${ }^{21}$ The judgment reviewed the evolution of the practice of the Board, discussing 21 cases reported between 1840 and 1929, 19 of which were appeals from Indian courts. ${ }^{22}$ The judgment then stated the Board's conclusions in this way: ${ }^{23}$

From this review of the decisions of the Board, their Lordships are of opinion that the following propositions may be derived as to the present practice of the Board and the nature of the special circumstances which will justify a departure from the practice:

(1) That the practice applies in the case of all the various judicatures whose final tribunal is the Board.

(2) That it applies to the concurrent findings of fact of two Courts and not to concurrent findings of the judges who compose such Courts. Therefore a dissent by a member of the appellate Court does not obviate the practice.

19 Srimati Bibhabati Devi v Kumar Ramendra Narayan Roy [1946] AC 508 (PC).

20 Gilrose Finance Ltd v Ellis Gould [2000] 2 NZLR 129 (PC).

21 Srimati Bibhabati Devi v Kumar Ramendra Narayan Roy, above n 19, at 513.

22 At 513-520.

23 At 521-522. 
(3) That a difference in the reasons which bring the judges to the same finding of fact will not obviate the practice.

(4) That, in order to obviate the practice, there must be some miscarriage of justice or violation of some principle of law or procedure. That miscarriage of justice means such a departure from the rules which permeate all judicial procedure as to make that which happened not in the proper sense of the word judicial procedure at all. That the violation of some principle of law or procedure must be such an erroneous proposition of law that if that proposition be corrected the finding cannot stand; or it may be the neglect of some principle of law or procedure, whose application will have the same effect. The question whether there is evidence on which the Courts could arrive at their finding is such a question of law.

(5) That the question of admissibility of evidence is a proposition of law, but it must be such as to affect materially the finding. The question of the value of the evidence is not a sufficient reason for departure from the practice.

(6) That the practice in not a cast-iron one, and the foregoing statement as to reasons which will justify departure is illustrative only, and there may occur cases of such an unusual nature as will constrain the Board to depart from the practice.

(7) That the Board will always be reluctant to depart from the practice in cases, which involve questions of manners customs or sentiments peculiar to the country or locality from which the case comes, whose significance is specially within the knowledge of the Courts of that country.

(8) That the practice relates to the findings of the Courts below, which are generally stated in the order of the Court, but may be stated as findings on the issues before the Court in the judgments, provided that they are directly related to the final decision of the Court.

Curiously, at least so far as current researches have extended, subsequent decisions applying those principles and textbook discussions make no reference to the extraordinary facts of the case. The only article in a legal periodical which does so is JP Eddy's article in the Law Quarterly Review, noted above. ${ }^{24}$

\section{A Srimati: the Case in the Courts}

In 1930, the respondent in the Privy Council instituted proceedings in the Court of the First Subordinate Judge at Dacca, seeking a declaration that he was Kumar Ramendra Narayan Roy, the second son of the late Raja of Bhowal (the Second Kumar), and was entitled to the one-third share in the properties described in the schedule comprising his inheritance. Srimati Bibhabti Devi, appellant in the Privy Council, married the Second Kumar in 1902. They had gone with a large party

24 JP Eddy "India and the Privy Council: The Last Appeal", above n 16. 
to Darjeeling. She claimed that he had died shortly before midnight on 8 May 1909 and had been cremated the next morning.

It was common ground that the Second Kumar was suffering from gummatous ulcers being the tertiary stage of syphilis and was taken for dead on 8 May 1909. The respondent in the Privy Council maintained that the body cremated on 9 May was not that of the Second Kumar. His case was that he, the Second Kumar, was taken for dead about dusk on the evening of 8 May; that arrangements were at once made for cremation; that the body was taken in funeral procession and placed in position for cremation when a violent storm caused the party to take shelter; that on their return after the rain had abated the body was no longer there; and that another body was procured by the funeral party and cremated the following morning. Srimati's case was that after the storm abated the Second Kumar was cremated.

His case was that while the funeral party was sheltering from the storm he was found still alive by four sanyasis (ascetics) who were nearby; that they took him away, looked after him and took him with them in their wanderings; that when he had recovered from an unconscious state he had no recollection of who he was or where he came from; that he lived and garbed himself as an ascetic would, smeared himself with ashes and grew long matted hair and a beard; that some 11 years later he recalled that he came from Dacca; that he made his way there in December 1920 or January 1921 and took up a position on a public walk on the margin of a river where people promenaded, and where he could be found seated day or night with a burning dhuni (ascetic's fire) before him; and that after gradual recognition of him as the Second Kumar which increased after the removal of the ashes, he declared his identity as the Second Kumar in the presence of many people on 4 May 1921, doing so mainly on the insistence of his sister who accepted him as such and was one of his principal witnesses.

Lord Thankerton observed that there was a very large body of evidence, oral and documentary, as to recognition of the plaintiff as the Second Kumar, or as to his identity with the Second Kumar, mentally, culturally or physically. ${ }^{25}$ He added that both the trial Judge and the Judges of the High Court had the advantage of a personal inspection of the plaintiff, which would not be available to the Board.

The trial itself lasted for 608 days. There were 1,500 witnesses and the judgment dated 24 August 1936 in favour of the plaintiff ran to some 500 pages. The appeal was heard by a Special Bench of the High Court at Fort William in Bengal consisting of Costello, Biswas and Lodge JJ and by decree dated 25 November 1940 (Lodge J dissenting), the judgment and decree of the trial court was affirmed and the appeal was dismissed.

25 Srimati Bibhabati Devi v Kumar Ramendra Narayan Roy, above n 19, at 513. 
The hearing before the Judicial Committee lasted 28 days. On 30 July 1946 after reviewing at some length the various challenges to the findings in the lower courts, the Judicial Committee concluded that the appellant had failed to establish any valid ground for departure from the practice of the Board. The Committee dismissed the appeal and affirmed the decision of the High Court.

Mr Eddy ended his brief discussion of the case by noting that shortly after the dismissal of the appeal by the Privy Council, the central figure in the protracted proceedings - the Second Kumar unhappily died. ${ }^{26}$

\section{CANADA}

Scott $v$ Attorney-General of Canada, ${ }^{27}$ Edwards v Attorney-General of Canada, ${ }^{28}$ and Campbell $v$ Hogg, ${ }^{29}$ were three highly unusual cases brought over a short period of time in which the Judicial Committee reversed the decisions of the Canadian courts. Scott and Edwards, which were statutory interpretation cases, can be dealt with quite shortly. Campbell $v$ Hogg, in which a person without legal training, having failed dismally at every step in Ontario, persuaded the Judicial Committee that an estate of which she was a beneficiary had suffered through the depredations of a lawyer-trustee, will take longer. In Deeks $v$ Wells, HG Wells was accused of literary piracy and Macmillans was joined as publisher of his The Outline of History. ${ }^{30}$

\section{A Scott v Attorney-General of Canada}

The Supreme Court Act 1907 of Alberta created a Superior Court of Civil and Criminal Jurisdiction styled on the Supreme Court of Alberta. The Court consisted of a Chief Justice and four puisne judges and the Act provided for the Court to sit en banc with a quorum of three judges. The Hon Horace Harvey was Chief Justice of the Supreme Court of Alberta having been appointed by Letters Patent of 12 October 1910. Amending legislation in 1913 provided for the Court en banc to become the Appellate Division of the Supreme Court and for all the judges to select periodically four of their number to constitute the Appellate Division. As a result of statutory changes in 1919 and 1920 and Letters Patent of 15 September 1921, the Hon David Lynch Scott was (purportedly) appointed the Chief Justice of Alberta and President of the Appellate Division of the Supreme Court. The Hon Horace Harvey (purportedly) became Chief Justice of the Trial Division of the Supreme Court and ex officio a judge of the Appellate Division.

26 JP Eddy "India and the Privy Council: The Last Appeal", above n 16, at 213.

27 Scott v Attorney-General of Canada [1923] 4 DLR 647 (PC).

28 Edwards v Attorney-General of Canada [1930] AC 124 (PC).

29 Campbell v Hogg [1930] 3 DLR 673 (PC).

30 Deeks v Wells [1933] 1 DLR 353 (PC). 
The Governor-General in Council referred five questions relating to the appointment of the Hon Horace Harvey to the Supreme Court of Canada. The answers of the Supreme Court (by a majority with two of the six judges dissenting) were in favour of the Hon Horace Harvey. ${ }^{31}$ The fifth answer as to the result of the case was that the Hon Horace Harvey held, and continued to hold, the office of Chief Justice of the Supreme Court of Alberta with the style and title of Chief Justice of Alberta. He was by law entitled to exercise the jurisdiction, office and function of such Chief Justice, and of President of the Appellate Division of the Supreme Court of Alberta.

The Judicial Committee (Viscount Haldane and Lords Buckmaster, Atkinson, Shaw and Sumner) first reviewed the 1907 statute, concluding from s 31 that the Chief Justice was not a necessary member of the Court sitting en banc and that much of the litigation assigned to the Supreme Court en banc by s 32 was not of an appellate character. ${ }^{32}$ They observed that the work was: 33

... so varied and copious that if the Province of Alberta should progress and become more populous the division of the Supreme Court into two or more branches, each dealing with its own share of the whole of the business assigned to the Court en banc, would probably become a matter of necessity.

This division indeed occurred in 1913, and it was true that under the provisions of that 1913 legislation the Hon Horace Harvey might neither be elected to sit, nor actually sit in the Appellate Division. The Board went on to consider the scheme embodied in the 1919 Act and concluded that it contemplated (and for its working required) the appointment of two Chief Justices, one for each of the two indicated branches or divisions.

On their analysis of the statutory provisions the Judicial Committee, per Lord Atkinson, did not consider that: ${ }^{34}$

... the fact that before the Act of 1919 was passed the Chief Justice was Chief Justice of the Supreme

Court prevented the legislature of Alberta from dividing the business of that Court into two branches, or necessarily entitled him to be or to be appointed Chief Justice of the Appellate Division, nor are they of opinion that his non-appointment to that office, or the appointment to it of the appellant [the Hon David Lynch Scott] constituted an infringement or evasion of any legal right which he possessed, or to which he was entitled.

They also noted that the salaries of the two Chief Justices were "precisely equal". ${ }^{35}$

31 Scott v Attorney-General of Canada [1922] 64 SCR 135 (SC).

32 Scott v Attorney-General of Canada, above n 27.

33 At [18] per Lord Atkin for the Court.

34 At [26].

35 At [24]. 
The appeal was allowed with the answer to the fifth question being that: ${ }^{36}$

Horace Harvey is not entitled to hold the office or to exercise the functions of the Chief Justice and President of the Appellate Division of the Supreme Court of Alberta, and that he is only entitled to hold the office on the Letters Patent dated the 15th September 1921.

The biography of David Scott in the Dictionary of Canadian Biography records the "crisis" that occurred when Horace Harvey was appointed Chief Justice and David Scott (who was 18 years older and had 10 more years experience as a Supreme Court judge) refused for the next decade to sit on appeals en banc, a refusal that ended only when the Privy Council confirmed his position as the premier judge. In 1924, David Scott received an LLD(Hons) from the University of Alberta and died later that year. At that point, and following a change of government, Horace Harvey was appointed Chief Justice in David Scott's place and continued as Chief Justice until his death in 1948. Professor WF Bowker KC's biography, titled The Honourable Horace Harvey, Chief Justice of Alberta, was published by the Canadian Bar Review in 1954. ${ }^{37}$

\section{$B$ Edwards v Attorney-General of Canada}

Section 24 of the British North America Act 1867 provided that:

The Governor-General shall from time to time, in the Queen's name, by instrument under the Great Seal

of Canada, summon qualified persons to the Senate; and, subject to the provisions of this Act, every

person so summoned shall become and be a Member of the Senate and a Senator.

For years, women's groups in Canada signed petitions and appeals to the Federal Government to open the Senate to women. Eventually, the Governor-General in Council referred the question raised in the petition of five prominent Alberta women to the Supreme Court of Canada: whether the words "qualified persons" in that section included a woman, and consequently whether women were eligible to be summoned to, and become members of the Senate of Canada. Henrietta Muir Edwards was the Vice-President for the Province of Alberta and of the National Council of Women for Canada; Nellie L McClung and Louise C McKinney were for several years members of the Legislative Assembly of Alberta; Emily F Murphy was a police magistrate in Alberta; and Irene Parlby was a member of the Legislative Assembly and a member of its Executive Council.

Chief Justice Anglin, and Duff, Mignault, Lamont and Smith JJ answered the question in the negative. ${ }^{38}$ The Chief Justice, whose judgment was concurred with by Lamont and Smith JJ and substantially by Mignault J, came to that conclusion on broad lines and mainly because of the

36 At [32].

37 WF Bowker The Honourable Horace Harvey, Chief Justice of Alberta (Canadian Bar Review, Toronto, 1954).

38 Edwards v Canada (Attorney General) [1928] SCR 276 (SC). 
inability of women to hold public office, and from a consideration of various cases decided under different statutes as to their right to vote for a Member of Parliament. Justice Duff decided on the narrower ground that on a close examination of the 1867 Act, "persons" in s 24 was restricted to members of the male sex.

The Privy Council (the Lord Chancellor, Lord Sankey, who delivered the judgment, and Lords Darling, Merrivale and Tomlin and Sir Lancelot Sanderson) allowed the appeal. ${ }^{39}$ They considered in turn:

- $\quad$ the external evidence derived from extraneous circumstances such as previous legislation and decided cases; and

- $\quad$ the internal evidence derived from the 1867 Act itself.

They immediately observed that the exclusion of women from all public offices was a relic of more barbarous days. ${ }^{40}$ But they noted that the necessity of the times often forced customs on man which in later years were not necessary, referring to the fact that the deliberative assemblies of the early tribes were attended by men under arms. They also concluded that under the common law of England, women were not in general deemed capable of exercising public functions except where there was a well-recognised custom; that the enactment of the interpretation statute known as Lord Brougham's Act 1850 did not appear to have greatly affected the current of authority; ${ }^{41}$ in reviewing the history of the development of legislatures in Canada, that where, instead of an express exclusion of women from public office, those entitled to serve were described under the word "person", different considerations arose and customs remained unchallenged long after the reason for them had disappeared; and that they did not think it right to rigidly apply decisions which commended themselves, probably rightly, to those who had to apply the law in different circumstances, in different centuries to countries in different stages of development to the Canada of today.

Turning to the internal evidence derived from consideration of the Act itself, the judgment emphasised that the 1867 Act "planted in Canada a living tree capable of growth and expansion within its natural limits". 42 The object of the Act was to grant a constitution to Canada and it was not the Board's duty or desire to cut down the provisions of the Act by a narrow and technical construction, but rather: ${ }^{43}$

39 Edwards v Attorney-General for Canada [1930] AC 124 (PC).

40 At 128 .

41 The Interpretation Act 1850 13\&14 Vict c 21, s 4. This section provided that in all acts words importing the masculine gender shall be deemed and taken to include female unless the contrary as to gender is expressly provided.

42 Edwards v Attorney-General for Canada, above n 39, at 138.

43 At 138 
... to give it a large and liberal interpretation so that the Dominion to a great extent, but certainly within fixed limits, may be mistress in her own house, as the provinces to a great extent, but within certain fixed limits, are mistresses in theirs.

Crucially, and noting that the word "persons" was used repeatedly in the Act, the Judicial Committee concluded: ${ }^{44}$

The word "person" as above mentioned may include members of both sexes, and to those who ask why the word should include females, the obvious answer is why should it not.

Then referring to the use of the masculine personal pronoun in various sections in the 1867 Act, the Board agreed with Justice Duff's invoking of s 1(2) of the Interpretation Act 1889, providing that words importing the masculine gender shall include females; and went on to point to various sections where in their context "person" had to include females.

The Board ended its judgment in this way: ${ }^{45}$

A heavy burden lies on an appellant who seeks to set aside a unanimous judgment of the Supreme Court, and this Board will only set aside such a decision after convincing argument and anxious consideration, but having regard

(1) To the object of the Act, viz, to provide a constitution for Canada, a responsible and developing State;

(2) that the word "person" is ambiguous and may include members of either sex;

(3) that there are sections in the Act ... which show that in some cases the word "person" must include females;

(4) that in some sections the words "male persons" is expressly used when it is desired to confine the matter in issue to males, and

(5) to the provisions of the Interpretation Act.

The Board had concluded that the word "persons" in s 24 did include women and that women were eligible to be summoned to and become members of the Senate of Canada. They accordingly allowed the appeal. Debate continues on Lord Sankey's "living tree" metaphor. ${ }^{46}$

44 Ibid.

45 At 143

46 Contrast PW Hogg's supportive discussion in Constitutional Law of Canada, above n 3, at [15.9(f)] and [33.7] and Professor James Allan's recent article vividly titled "Statutory Bills of Rights: 'You Read Words In, You Read Words Out, You Take Parliament's Clear Intention and You Shake it All About' - Doin' the Sankey Hanky Panky" in Tom Campbell, KD Ewing and Adam Tomkins (eds) The Legal Protection of Human Rights: Sceptical Essays (Oxford University Press, Oxford, 2011) 108. 


\section{Campbell v Hogg}

Mrs Ethel Bethune Campbell, born in 1880, grew up in Toronto as part of the legal, judicial and political establishment. Her father, James Bethune QC, was a former politician, a Law Society Bencher and a prominent barrister. She was the youngest of the children by 13 years and was only four years old when her father died in 1884 aged 44 . He left his entire estate of some $\$ 60,000$ (exclusive of realty), to his widow.

Mrs Campbell's mother relied on her brother-in-law, Ottawa lawyer William Drummond Hogg, to look after the estate and invest sums she passed over to him in mortgages to provide her income. In 1895 she married Sir William Howland, Ontario's former Lieutenant Governor, who died in 1907.

In 1907 Ethel Bethune married the Reverend Thomas Campbell and they moved to Boston where he was Rector of an Episcopalian Church.

By 1915 Mrs Campbell's mother's mental powers began to fail. In 1922 by an order of the Supreme Court of Ontario, made on the application of Mrs Lindsay and in the presence of Mrs McDougald (Mrs Campbell's sister) and Mrs Campbell, the Toronto General Trusts Corporation was appointed Committee of her estate, and Mrs Lindsay and Mrs McDougald Committee of her person. Mr Hogg became a QC, Senior Bencher in Ontario and eventually chairman of directors of the Toronto General Trusts Corporation. Mrs Campbell's mother, Lady Howland, died in 1924. From then, Mrs Campbell battled against the largely closed ranks of the legal establishment until 1930, when as a litigant-in-person she successfully argued her appeal before the Privy Council. Those struggles continued in Ontario after 1930 as she sought to recover the fruits of that victory.

In 1940 Mrs Campbell self-published a book titled Where Angels Fear to Tread, recounting her struggles. ${ }^{47}$ In 2004 the Osgoode Society for Canadian Legal History republished her book with an extensive introduction, epilogue and research notes by Professor Constance Backhouse and her sister Madam Justice Nancy L Backhouse, titled The Heiress vs The Establishment: Mrs Campbell's Campaign for Legal Justice. ${ }^{48}$ The Appendix to that book lists the majority of the legal matters heard in the estate litigation, 10 up to and including the decision of the Privy Council, and 14 subsequent, recounting intransigent battles over costs and interest and extending to Mrs Campbell's unsuccessful attempts to have Mr Hogg disbarred and to charge him with criminal misconduct.

Book one of Where Angels Fear to Tread recounts how, after the Supreme Court made those protective orders in 1922, Mrs Campbell and her sister found amongst their mother's possessions what appeared to be a copy of a will appointing the Trust Company as executor and under which she

47 Elizabeth Bethune Campbell Where Angels Fear to Tread (St John's Rectory, Boston, 1940).

48 Constance Backhouse and Nancy L Backhouse The Heiress vs The Establishment: Mrs Campbell's Campaign for Legal Justice (UBC Press for the Osgoode Society for Canadian Legal History, Vancouver, 2004). 
was residuary legatee. The initial response by the Trust Company was that no will had ever been signed by Lady Howland; next, then successively, that the will could not be found; that her sisters had taken out administration and the estate was about to be distributed equally between the three sisters; after administration of the estate was stopped, that the will had been executed by the mother but that she had received and subsequently revoked the will by destroying it while of sound mind; and that in the course of the hearing of an appeal to the Appellate Division, the Chief Justice required the three sisters to confer with the Justices in the interests of a settlement which was achieved with the Chief Justice also insisting that Mrs Campbell's counsel add in that "to the day of her death Lady Howland was of sound mind and testamentary capacity." 49 That settlement meant, too, that Mrs Campbell had standing as a litigant in person when she ultimately argued her appeal in London, asserting that she had suffered through the depredations of Mr Hogg as lawyer-trustee.

In their judgment of 1 May 1930 the Judicial Committee (Lords Blanesburgh, Tomlin and Russell of Killowen and delivered by Lord Blanesburgh) concluded that as trustee Mr Hogg had breached his elementary duty to keep an accurate account of the trust property and always be ready to render it when required; that almost any statement made by Mr Hogg who was a local Director of the Trust Company would unreservedly be accepted by its manager (as had happened with his misleading reply to the request by the Trust Company for a detailed list of Lady Howland's investments); and that while they would be slow to conclude that any statement on oath by Mr Hogg in this or any other case could be a statement he knew to be untrue: ${ }^{50}$

... they are much affected by his tampering with business books and his shifting statements on the subject, while in his evidence at the hearing, just as in his correspondence before it, he repeatedly made statements, in fact quite incorrect, with an assurance no less positive than displayed when his statements were accurate. Without imputing any moral blame to Mr Hogg, for they remember his years and his prepossessions, their Lordships are unable to profess themselves satisfied either with regard to the correctness of his testimony on any disputed item or generally in relation to this case.

The judgment went on to reject the submission for Mr Hogg that the findings of the courts below on all questions in debate amounted to concurrent findings of fact which following usual practice would not be disturbed. The judgment repeated that: ${ }^{51}$

... the so-called findings were based on an erroneous proposition of law to such an extent that with that proposition corrected they disappear. Within the Board's rule there has been no finding at all. The complaints made by the appellant must therefore be investigated by their Lordships afresh.

49 Ibid at 51.

50 Campbell v Hogg, above n 29, at 687.

51 At 687. 
Following a review of the relevant material, the Board concluded that the irregularities on $\mathrm{Mr}$ Hogg's part which they had identified would have attracted the concern of the Canadian judges, had it not been for their mistaken view that Mr Hogg's relation to Lady Howland was one of agency without fiduciary responsibility, and that nearly all the expense of the proceedings was attributable to the irregularities. ${ }^{52}$

Allowing the appeal, the Board concluded that there remained in Mr Hogg's hands the net sum of \$7,027.34; that Mr Hogg was responsible for the heavy costs of the proceedings throughout and should pay the appellant three-fourths of all her costs without recourse to the Trust Estate; and that whether the balance of her costs should be paid out of the $\$ 7,027.34$ before division between the three sisters would have to be a matter of agreement between Mrs Campbell and her sisters.

\section{Deeks v Wells}

Only two years later another celebrated Canadian, Miss Florence Deeks, argued her own appeal in London. She would have been heartened by the immense publicity in Canada of Mrs Campbell's case and by the opening comment by Chief Justice Latchford in his judgment in the Appeal Division of the Ontario Supreme Court: ${ }^{53}$

It is greatly to the credit of Miss Deeks that her presentation in person of this appeal has been as full and effective as in the circumstances it could have been argued by the most able counsel.

Miss Deeks claimed breach of copyright. In substance, however, she claimed for breach of confidence in permitting her manuscript The Web (involving the whole history of the world with the special object of emphasising the important part women had played in its development) to be used without her consent. She had spent four years researching and writing her work and entrusted the manuscript to the Macmillan Company of Canada in August 1918 (which the Board found had been returned to her in April 1919), having asked their advice as to the prospects of publication and also whether there would be any objection to her use of certain extracts from an historical publication of which the copyright was owned by Macmillans in London. The action was also brought against $\mathrm{Mr}$ HG Wells who was said to have used the manuscript improperly as the foundation of his book The Outline of History, and against Macmillans and other publishers of his book.

The evidence of Mr Saul of Macmillans in Canada was that he had read the manuscript twice and had not parted with it before he left Macmillans in November 1918; the evidence taken on commission of Sir Frederick Macmillan (chairman of Macmillan's Board in London) that every manuscript came before the Board and that the Board had never seen such a manuscript or heard of Miss Deeks; and of Mr Wells was that he had never seen the manuscript, that he did not know of Miss Deeks, and that he had not taken any part of the information that she had put in her manuscript

52 At 689 .

53 Deeks v Wells [1931] 4 DLR 533 at 533. 
from that manuscript or from Miss Deeks herself. And there was no direct evidence that the manuscript ever did in fact leave Canada.

The Judicial Committee (Lords Atkin, who delivered the judgment, Tomlin and Thankerton) said that whether or not the manuscript was handed over to Mr Wells, or whether or not it had been improperly used by him, were pure questions of fact. The Committee accepted that both Canadian courts had found against Miss Deeks and in accordance with the usual practice the Board would not hear an appeal suggesting those findings were wrong. But, because Miss Deeks appeared in person and evidently thoroughly believed in her case, it was important in everybody's interests for it to be fully heard and decided, which the Board proceeded to do.

They reviewed the direct evidence and went on to consider the intrinsic evidence to be derived from a comparison of the two works. On that point they were not prepared to say that in the case of two literary works, intrinsic evidence of that kind may not be sufficient to establish a case of copying, even if the direct evidence is all the other way and appears to be evidence that can be accepted. ${ }^{54}$ But, they added, such evidence must be of the most cogent force before it can be accepted as against the oath of respectable and responsible people whose evidence otherwise would be believed by the Court.

Miss Deeks submitted that when you compare the one work with the other you find such an accumulation of similarities, of like omissions, of plan, of phrases, of mistakes, that the inference is irresistible that Mr Wells did in fact have her work before him when he composed his work. In that regard she also relied on the evidence of three literary experts who had concluded it could be inferred that one work was a copy of the other.

The Judicial Committee went on to review those matters, concluding: ${ }^{55}$

... they are quite convinced that the case made in this respect is quite insufficient to displace the conviction that there was in this case no copying in fact. The suggested similarities can be explained by the nature of the work, which has common elements, and by the fact that both writers must have had recourse to authorities which were common to both ... not only did Miss Deeks fail to make out her case, but ... it was definitely established that the manuscript in this case did not leave Canada and that Mr Wells did not have access to it and did not use it at all in the preparation of his work.

As they did in the case of Campbell v Hogg, the Osgoode Society for Canadian Legal History published a book on Miss Deeks' case by Professor AB McKillop (described by the Society as one of Canada's pre-eminent historians), The Spinster and the Prophet: Florence Deeks, HG Wells and

54 Deeks $v$ Wells, above n 30, at 358.

55 Ibid. 
the Mystery of the Purloined Past, ${ }^{56}$ which suggests that how the Deeks manuscript could have reached Mr Wells and why she had a legitimate case.

\section{NEW ZEALAND}

Buckley (Attorney-General of New Zealand) v Edwards, ${ }^{57}$ Wallis v Solicitor-General, ${ }^{58}$ and Massey v New Zealand Times Co Ltd, ${ }^{59}$ were three cases with highly unusual features. The Judicial Committee reversed decisions of the Court of Appeal in two of these cases. In Buckley $v$ Edwards the (purported) appointment by the Governor of Worley Bassett Edwards as a Supreme Court judge, without legislation allowing appointment of a sixth judge and parliamentary appropriation of salary, was held invalid. In Wallis $v$ Solicitor-General the Solicitor-General was castigated and the Court of Appeal was consequentially criticised over an action for the administration of the trusts of a settlement. This led to the historic "Protest by the Bench and Bar" following receipt of the judgment, the text of which is recorded at the end of the New Zealand Privy Council Cases volume. ${ }^{60}$ In Massey $v$ New Zealand Times Co Ltd, the then Leader of the Opposition (and within weeks to be Prime Minister of New Zealand), failed in his defamation case against a newspaper where he had been depicted as the central figure in a vicious cartoon.

Before discussing those cases in turn it may be worthwhile noting some clear impressions that emerge from reading all the Judicial Committee decisions in the New Zealand Privy Council Cases reports. There are 94 substantive judgments on appeal and three petitions to the Privy Council. The judgments tended to be short and the 97 cases are contained in 748 pages, averaging less than eight pages each. An obvious factor present was that in the vast majority the Judicial Committee was exercising the correction of error role of an appellate court and could do so succinctly. There were very few appeals that could be viewed as developing the common law or modifying the process of interpretation of statutes.

Next, the application of the common law to Māori, the impact of settler governments and of the Land Wars, the functioning of Native Land Courts or the cognisance of Māori customary law arose in eight cases.

Finally, most of the appeals, especially in the 19th century, were argued by London-based counsel sometimes along with counsel from New Zealand, usually in a junior role. This was no doubt due in part to the cost and time involved in travel between London and New Zealand before

56 AB McKillop The Spinster and the Prophet: Florence Deeks, HG Wells and the Mystery of the Purloined Past (McFarlane Walter and Ross, Toronto, 2000) at 387-402.

57 Buckley (Attorney-General of New Zealand) v Edwards [1892] AC 387 (PC).

58 Wallis $v$ Solicitor-General [1903] AC 173 (PC).

59 Massey v New Zealand Times Co Ltd (1912) NZPCC 503.

60 "Protest of Bench and Bar, April 25, 1903" [1849-1932] NZPCC Appendix 730. 
the advent of regular steamship services. And there were no instances of an appellant arguing the case in person.

\section{A Buckley (Attorney-General) v Edwards}

Robin Cooke, reviewing the 19th century judges in Portrait of a Profession, recounts Justice Edwards' career. ${ }^{61}$ There is an equally lively account in Professor Bernard Brown's biography of the judge. ${ }^{62}$ Lord Cooke begins his account in this way: ${ }^{63}$

Few judicial careers can have been as turbulent as that of Worley Bassett Edwards. Storms raged about him throughout his life within the law and without. Indeed in large part he created them.

The Atkinson Government sought to persuade Mr Edwards to undertake an inquiry as a Native Lands Commissioner. After much negotiation (including his suggestion that to attract a leader of the bar to accept appointment it would be necessary to offer a Supreme Court judgeship as well) he was appointed Commissioner along with Mr John Ormsby, and was also appointed as the sixth judge. When the Government was defeated at the polls, the incoming Ballance administration questioned the validity of that appointment. A divided Court of Appeal (Richmond, Williams and Denniston JJ, Prendergast CJ and Connolly J dissenting) dismissed the challenge, resulting in the Privy Council appeal.

Reflecting the significance of the case for New Zealand and throughout the Empire, seven judges heard the appeal (The Lord Chancellor (Lord Halsbury), Lords Watson, Hobhouse, Herschell, Macnaghten and Hannen and Sir Richard Couch). Lord Herschell explained:64

The question raised is one of great importance, the contention on the part of the Respondent being that as the law stands in New Zealand the Governor has the power of adding without limit to the number of the Judges of the Supreme Court of that Colony, without express parliamentary sanction, and in the absence of any parliamentary provision for the salaries of the judges so appointed.

Lord Herschell had begun the judgment by recording that on 2 March 1890 the Governor of New Zealand had issued a commission to Mr Edwards appointing him a puisne judge of the Supreme Court, to hold office during good behaviour. ${ }^{65}$ The previous day, the then Premier had written him an explanatory letter stating that it had appeared to the Government that the office of Commissioner was of such importance that the appointee should have the status of a judge of the

61 Robin Cooke (ed) Portrait of a Profession (AH and AW Reed, Wellington, 1969) at 55-56.

62 Bernard Brown "Edwards, Worley Bassett" Te Ara (New Zealand Dictionary of Biography) $<$ www.teara.govt.nz $>$.

63 Robin Cooke (ed) Portrait of a Profession, above n 61, at 55.

64 Buckley (Attorney-General of New Zealand) v Edwards, above n 57, at 206.

65 At 204. 
Supreme Court. Therefore he, Mr Edwards, would be appointed to that office also. The letter added that the demands on the time of the judges caused unavoidable delay in the despatch of business, and that it was hoped that this arrangement, by which Mr Edwards would afford occasional assistance in the Supreme Court work, would temporarily meet the requirements. The judgment goes on to record that his appointment as Commissioner came to an end on 31 March 1891, that no salary had been provided for him as puisne judge by the General Assembly at the time of his appointment or since (in other words, up to 21 May 1892 when the judgment was delivered), nor was there any parliamentary sanction for the appointment unless it was to be found in prior legislation. ${ }^{66}$

After reviewing the historical position generally and the New Zealand legislation in detail the Board allowed the appeal. They emphasised that there was constitutional and fiscal provision for five judges only, and the importance reflected in the legislation of maintaining the independence of the judges by ensuring that they were not dependent for their judicial salary on the Ministry of the day and the goodwill of Parliament. ${ }^{67}$

A few weeks later, when the status of the decisions Mr Edwards had made as a judge was raised in the House of Representatives, the Prime Minister (the Hon John Ballance) stated that the Law Officers were considering the position and if his judgments were not valid in law a validation Bill would be introduced. ${ }^{68}$ No Bill was introduced but the question reached the Court of Appeal in In Re Aldridge on a habeas corpus motion to discharge the applicant who had been convicted and sentenced to imprisonment by Mr Edwards. ${ }^{69}$ The application failed. The Court (Prendergast CJ and Richmond, Denniston, Connolly and Ward JJ) held it was not possible to challenge the validity of the judgments of one who, although not lawfully appointed, exercises the office of a judge under a bona fide belief of right and who is recognised and treated as a judge.

The discomforted Mr Edwards resumed practice until he was regularly appointed to the Court in 1896. As discussed by Lord Cooke and Professor Brown, ${ }^{70}$ while well-regarded for his judgments, his conduct in the Court in Auckland provoked an organised protest by the Auckland bar and when transferred to Wellington he fell out with most of the bar there and ended his judicial career wrangling with the Department of Justice.

66 At 205.

67 At 212 and 210.

68 (15 July 1892) 75 NZPD 500.

69 In Re Aldridge (1893) 15 NZLR 361 (CA).

70 Robin Cooke (ed) Portrait of a Profession, above n 61; Bernard Brown "Edwards, Worley Bassett" above n 62. 


\section{B Wallis v Solicitor-General}

In 1848, Māori chiefs wrote to the Governor giving up land at Porirua to the Bishop of New Zealand and his successors for a college. The Lieutenant-Governor sanctioned the proposed cession of the land and a Crown grant was issued for the land totalling some 500 acres to be held in trust for the maintenance of a school "so long as religious education, industrial training and instruction in the English language shall be given to the youth educated or maintained [there]." Because of the rough and inaccessible state of the land it was made available for grazing animals and by 1897 no school had been erected. With a falling off of the Māori population the trustees concluded that a school as contemplated by the original donors could never be achieved. They applied to the Supreme Court for directions and after negotiations proposed a scheme.

The Chief Justice, Sir James Prendergast, rejected the contention of the Solicitor-General (who had been named as a party) that the endowment had reverted to the Crown. ${ }^{71}$ He held that the general purpose of the foundation was charity and reserved the matter for further consideration. Sir James Prendergast having retired, the matter came before the new Chief Justice, Sir Robert Stout. Edwards J and the trustees proposed a fresh charitable scheme that the Judges adopted, rejecting the Solicitor-General's renewed objections, holding they were bound by Chief Justice's decree.

The Court of Appeal (Williams, Denniston, Connolly and Cooper JJ) decided in favour of the Crown on narrow grounds. These were dismissed by the Judicial Committee (Lords Macnaghten and Lindley, Sir Ford North and Sir Arthur Wilson) in robust language charging that the SolicitorGeneral "seems to have thought it not inconsistent with the traditions of his high office to attack a charity which it was prima facie his duty to protect". ${ }^{72}$ Moreover, they criticised the Court of Appeal at length, ending by asking: ${ }^{73}$

Why should the Court [of Appeal] attribute to the government of the past more than childlike simplicity in order that the Government of today may confiscate and appropriate property which never belonged to the Crown and which the Crown encouraged the rightful possessors to dedicate to charity?

It would be a mistake to characterise the criticisms of the Judicial Committee and the immediate detailed protest by the New Zealand bench and bar as an unfortunate family storm in a teacup. Rather they should be viewed as a tragedy calling for some explanation. The Judicial Committee, applying the standard English approach to trusts without adequately appreciating the social and cultural setting, branded the Solicitor-General and the Court of Appeal as miscreants. In turn, the furious New Zealand reaction attacked the Judicial Committee's judgment with the Chief Justice, Sir Robert Stout, pointing out perceived gaps and errors in the Board's understanding of the relevant

71 Noted as part of the narrative by the Privy Council.

72 Wallis v Solicitor-General, above n 58, at 29.

73 At 32. 
New Zealand laws and local conditions and gratuitously explaining how they had erred in a number of other New Zealand appeals.

In doing so, the Chief Justice was reflecting wider discussions concerning the Privy Council's oversight of their judicial decisions expressed at that time in the self-confident, self-governing colonies. In his article the following year titled "Appellate Tribunals for the Colonies", ${ }^{74}$ the Chief Justice reviewed the pros and cons of local appellate courts compared with the Privy Council and concluded: ${ }^{75}$

I submit that the advantages of local Appellate Courts transcend their disadvantages. The present system is often a denial of justice to many litigants on account of delay, cost and the ignorance of the external Judges of what our laws have been, and are, and of want of acquaintance with our environment. The psychological effect of dependence on some external power for the performance of our highest duties as citizens of these new nations should also not be lost sight of.

In her 1959 article, ${ }^{76}$ Professor Enid Campbell charted the political history of appeals to the Privy Council in the first half of the 20th century and the discussions which took place at Imperial Conferences, including the agreement reached at the 1911 Imperial Conference for the composition and judicial membership of a final Imperial Appeal Court in two divisions, one for the United Kingdom and the other for the overseas Dominions. Norman Bentwich notes that the Appellate Jurisdiction Bill had been introduced by the Government in 1911 and was "likely to be reintroduced this session". ${ }^{77}$

But it was not to be. Professor Campbell ended her account of the history in this way: ${ }^{78}$

After the initial flush of enthusiasm and optimism during the first 20 years of the century the notion of a truly Imperial or Commonwealth Court of Appeal appears to have become a lost cause. It would be difficult to assign one single reason to the breakdown of discussions and negotiations but it is probable that the following factors were not without influence: (a) the lack of agreement upon whether the court should be itinerant; (b) the difficulty of obtaining Dominion judges who would become resident in London; (c) the fact that the proposed merger of the House of Lords and the Judicial Committee raised the controversial issue of reform of the House of Lords; (d) the growth of the feeling in some Dominions that their interests would be better served by judicial autonomy.

74 Robert Stout "Appellate Tribunals for the Colonies" (1904) 2 CLR 3.

75 At 13.

76 Enid Campbell "The Decline of the Jurisdiction of the Judicial Committee of the Privy Council", above n 7.

77 Norman Bentwich The Practice of the Privy Council in Judicial Matters (Sweet and Maxwell, London, 1912) at vii.

78 Enid Campbell "The Decline of the Jurisdiction of the Judicial Committee of the Privy Council", above n 7, at 199. 


\section{Massey v New Zealand Times Co Ltd}

The immediate background was that a scurrilous pamphlet directed against the then Prime Minister was published and discussed in the House of Representatives. Mr Massey, Leader of the Opposition, repudiated the pamphlet, denying any connection with it. The newspaper then published a paragraph charging the Opposition with conducting a campaign against the Government based on allegations and innuendos of dishonesty and deceit and the same day the Attorney-General (Dr JG Findlay) made a speech in the Legislative Council in which he accused the Opposition of having hitched their wagon to a lie.

Two days later, the newspaper published a cartoon representing a man, obviously Mr Massey, in the act of hitching a donkey labelled "Ananias" to a wagon painted on the side "We are the party" and laden with bundles labelled respectively "pamphlets free", "startling revelations", "expense", "private calumny", "dead men's characters", "scandal mongering", "Tammany" and "defamation", and a bucket labelled "Mud". Underneath the cartoon were the words "Hitch your wagon to a star Emerson" and "Hitch your wagon to a lie - Dr Findlay's amendment".

The jury found that the figure represented Mr Massey, and were of opinion that it was a political cartoon "pure and simple and is not libellous."79

The crucial ground pleaded for Mr Massey was that, having held that the cartoon represented $\mathrm{Mr}$ Massey, the jury could not reasonably have reached the two conclusions that it was a political cartoon only and not libellous of Mr Massey personally.

The Supreme Court (Stout CJ and Chapman J) dismissed the motion for a new trial, holding that the jury was entitled to conclude on the evidence that the imputation made in the pleaded innuendo was not made out. The innuendo was described as: ${ }^{80}$

... the plaintiff, who was depicted in the cartoon or pictorial representation as hitching a wagon was responsible for the free distribution of the improper and scurrilous pamphlet, or had taken part in the free distribution thereof, and that the plaintiff had been guilty of a despicable act and was a liar.

The Court of Appeal was divided on the appeal (Williams and Sim JJ favouring dismissal of the appeal and Denniston and Edwards JJ being of the opinion that the verdict was against the weight of the evidence and the cartoon was undoubtedly libellous). In that situation the decision of the Supreme Court was affirmed. ${ }^{81}$

79 Massey v New Zealand Times Co Ltd (1911) 30 NZLR 929 (report for both the SC Wellington and CA) at 931.

80 Ibid.

81 Ibid. 
Lord Atkinson, delivering the judgment of the Judicial Committee (Lords Macnaghten, Atkinson and Shaw) concluded on the evidence, including discussion of what various witnesses had implied from the cartoon, that: ${ }^{82}$

... it was impossible to hold that the jury could not as reasonable men have come, honestly and

consistently, to the conclusions to which they had come on both questions submitted to them

The appeal was dismissed.

\section{SOME CONCLUDING COMMENTS}

What conclusions can we draw from these unusual cases in the Privy Council? I suggest there are four:

First, for over 100 years the Judicial Committee of the Privy Council Act 1833 provided a sufficiently flexible framework for the Judicial Committee to function as the final court for the British Empire, to take account of the differences between the various colonies enjoying a substantial measure of self-government and the more dependent territories of the Empire.

Second, the Judicial Committee protected its capacity to focus on its crucial role as the Imperial Tribunal, broadly applying the common law of England subject to local conditions. It did so in two ways. One was procedural, respecting local conditions by ordinarily not entertaining civil appeals where there were concurrent findings of fact in the courts below and by rarely granting leave to appeal in criminal cases. The other way, reflected in Indian appeals, ensured that judges with very substantial judicial experience in India sat in their own right as assessors or full members of the Board to provide the special expertise that London-based judges lacked.

Coupled with that was an awareness that judges in the older colonies knew the common law, many having been trained in England, and an assumption that counsel could ordinarily be expected to bring relevant local differences to the attention of the Board. Inevitably, it seems in some cases the Judicial Committee may have assumed too readily that they had an adequate picture of the local setting, which at times led to judicial and governmental tensions in the relationships, and suggestions for changes in the composition and sitting arrangements of the Board. ${ }^{83}$

Third, and reflected in Viscount Haldane's remarks cited at the beginning of this article, the Judicial Committee developed an understanding of local communities, at least of India and Canada where the great majority of their cases originated and where so many counsel came from, as leading or as junior counsel to London-based silks who specialised in those areas.

82 Massey v New Zealand Times Co Ltd, above n 59, at 509.

83 As reflected in the Wallis saga and in the articles by Sir Robert Stout and Professor Campbell above. 
Fourth, the Judicial Committee had the capability to look with fresh eyes at issues which had divided colonial courts as, perhaps demonstrated in the three Canadian cases, Scott $v$ AttorneyGeneral of Canada, Edwards v Attorney-General of Canada and Campbell v Hogg and, too, in Buckley (Attorney-General of New Zealand) $v$ Edwards and Massey v New Zealand Times Co Ltd. 